\title{
Senescência ocular e o século XXI
}

$\mathbf{O}$ sentido da visão é responsável por cerca de oitenta e cinco por cento da integração do ser humano com o meio que o rodeia. Isso é perfeitamente compreendido quando fechamos os olhos por um breve intervalo de tempo de apenas cinco segundos, e percebemos como tudo fica diferente.

Os órgãos maiores da visão - os olhos - são estruturalmente pequenos em dimensão e frágeis na consistência, porém extremamente importantes na função, além de serem riquíssimos na expressão.

Os olhos são as janelas da alma; ao brilhar na alegria ou lacrimejar no choro, a tradução do sentimento e das sensações, enfim, os nossos guias tanto nos momentos de satisfação quanto nas desilusões!

Esse dom divino, assim como as outras partes do corpo humano, também envelhece, sofre desgastes, pode sediar doenças e ser alvo de processos degenerativos.

Se considerarmos as linhas de cortes epistemológicos relacionadas com a envelhescência ocular que se estabelecem no decorrer da vida, podemos registrar três momentos como os mais significativos: o primeiro é o que acontece por volta da quarta década, em que já não é mais possível ler sem o auxílio de óculos. É a presbiopia, definida como a dificuldade de visão para perto causada pela perda da acomodação - capacidade de enfocar objetos e diferentes distâncias.

Também nesse momento, aproximadamente $2 \%$ da população de todas as raças começa a desenvolver uma doença ocular denominada glaucoma - oftalmopatia que, se não controlada, lesa gradualmente o nervo óptico, podendo causar cegueira. Essa entidade tem na elevação dos níveis suportáveis de pressão intraocular o seu principal fator de risco.

Ainda a partir dos quarenta anos, enfermidades como a hipertensão arterial e a diabetes, se não compensadas, podem cursar com manifestações oculares na região do fundo do olho, a urgirem pela aplicação de tratamento a base de raios laser para evitar o comprometimento severo da visão.

O segundo momento ocorre na quinta década quando, somados aos antes descritos, podem se instalar dois outros males de considerável relevância (detectados mais frequentemente no sexo feminino, de provável correlação com distúrbios hormonais), que são: o Olho Seco, causado pela diminuição e/ou desorganização do filme lacrimal, o que requer a utilização permanente de colírios de lágrima artificial; e as deformidades da pálpebra, causadas pela deposição de excesso de gorduras, que produzem as bolsas palpebrais e os xantelasmas, situações resolvíveis com procedimentos cirúrgicos de pequeno porte.

O terceiro momento ocorre a partir dos sessenta anos, quando as primeiras estruturas oculares que se formam na vida embrionária evidenciam que também são as primeiras que desenvolvem senescência. É quando advêm as doenças do cristalino, da retina e dos nervos cranianos relacionados com o aparelho visual. Com a perda da transparência da lente natural do olho, instala-se a catarata, que leva à baixa da acuidade visual, sendo tal situação quase sempre reversível com a aspiração do cristalino envelhecido e sua respectiva substituição por uma lente intraocultar artificial.

Também, a partir dessa faixa de idade, pode ocorrer comprometimento da retina, em especial, a mácula, quando pode instalar-se a doença conhecida como Degeneração Macular Relacionada com a Idade (DMRI) que leva, na maioria das vezes, à perda significativa da eficiência visual. Entretanto, os avanços no melhor conhecimento das drogas que atuam, impedindo o crescimento vascular e a sua respectiva aplicação diretamente no interior do olho, despontam como direção alvissareira para o controle dessa enigmática doença. 
Ainda no transcorrer da idade avançada podem advir distúrbios neurológicos, denunciados por meio de alteração dos movimentos oculares, tanto na horizontalidade quanto no sentido vertical, como, por exemplo, a perda da capacidade de girar os olhos na direção para cima, que pode vir a representar um alerta sobre o possível futuro estabelecimento de doença como o Mal de Parkinson.

O conhecimento dessas noções, por parte da população em geral, deve ser entendido como princípio de educação em saúde, na busca por viver mais e com qualidade, assim como a atenção da comunidade oftalmológica em voltar-se, cada vez mais, para a gerontologia é deveras importante, considerando-se ser a população de idosos centenários uma realidade crescente em todo mundo no século XXI.

Cláudio Chaves

Instituto de Oftalmologia de Manaus e Universidade Federal do Amazonas 